\title{
The Perception of Islamic Youth to The Phenomenon of Hubbu Ilahi
}

\author{
Muhammad Roy Asrori1 ${ }^{*}$, Zakiyatul Fitriyah², Ahmad Faikul Anam³, Ahmad \\ Nashih Anis Zubaidy4, Zubaidah ${ }^{5}$ \\ 1-5MA Integratif NU Al-Hikmah, Malang Regency, 65156, Indonesia \\ *Corresponding Author E-mail: muhammadroyasrori09@gmail.com
}

\begin{abstract}
Youth life is closely related to spiritual activity. The phenomenon that is still encountered is Hubbu Ilahi, or the love attitude of Allah SWT. This phenomenon is presumed that adolescents only state and do not know the consequences of their attitudes. So, this study aims to determine the perceptions of today's adolescents on the phenomenon of Hubbu Ilahi. This research is descriptive qualitative research with a survey research method. This study used a purposive random sampling technique to 39 adolescents. Data collection used a questionnaire with the google form platform. Then, the data were analyzed using: data presentation, data reduction, and concluding. The results showed that adolescent respondents stated the consistency of love of the Quran, love of Rasulullah (SAW), love of the Prophet's Sunnah, and love of the Akhirat life. However, the busyness of the world blocks the proven proof of love. The analysis concluded that only $7.7 \%$ of adolescents fit Hubbu Ilahi's criteria.
\end{abstract}

Keywords: Perception, Islamic youth, Hubbu Ilahi, Qomiuth Thughyan

\section{INTRODUCTION}

Adolescence is a period of transition from childhood to adulthood (Mufarriq, 2021). Adolescent life is influenced by environmental parties, including family, school, and community. Several things that encourage adolescents to deviate include: (1) self-problems and not understanding the solution, (2) the role of social institutions that are less strong, and (3) lack of self-control in life situations. (Nurmalisa \& Adha, 2016). Another fact was that open access to technology and information media had had an effect on morals, so strengthening religion-based morals was very important (Muthohar, 2013; Taopan et al., 2019) because social education has been going on everywhere (Rusydiyah, 2020). So, the more often there is a teenage moral decadence, the more moral emergency will be for the next life.

The symptoms of moral decadence will continue throughout the ages. The opportunities for doing deviant behavior are opening up. In addition, many youths began to prioritize education rather than religious knowledge. Youth have rarely touched religious knowledge. Moreover, religious knowledge is not well understood and practiced. Wrong religious knowledge and acts of worship will exacerbate moral decadence. So, the teenage phenomenon is currently a serious challenge for educators (Ghafur, 2019; Setyoningsih, 2018).

An eccentric phenomenon among Muslim adolescents is the Hubbu Ilahi (Love to Allah) phenomenon because religious teachings during childhood were strived to have a love story for Allah and the Prophet (Masganti, 2016). This phenomenon can be observed in learning tauhid. So, this phenomenon is important to investigate the symptoms of small/subtle processes of moral decadence. Morals embedded in adolescence will affect adulthood. The civilization of the Muslim community needs to be supported by the younger generation who have good morals. However, not all adolescents have a good religious, moral

\footnotetext{
* Copyright (c) 2021 Muhammad Roy Asrori et.al

This work is licensed under a $\underline{\text { Creative Commons Attribution-ShareAlike 4.0 International License. }}$
}

Received: February 28, 2021 ; In Revised: April 2, 2021 ; Accepted: Juny 3, 2021 
foundation. Survey research is needed to collect perceptions of millennial adolescents (Arifin, 2020; Semiawan, 2010).

Previous research on Hubbu Ilahi in the literature showed that Hubbu Ilahi was very close to Islamic education (Haslinda et al., 2020). The research also concluded that Hubbu Ilahi's attitude would affect Islamic education activities, which is expected to improve the quality of Islamic education. However, the research has not presented the valid criteria of Hubbu Ilahi. This conclusion was also found in a descriptive study of children aged 5-6 years, which showed that children's education through a direct approach and habituation fosters an attitude of Hubbu Ilahi. (Kristiawan \& Fitria, 2018). Likewise, in research on Hubbu Ilahi via the story method (Masganti, 2016). The studies have not evaluated the Hubbu Ilahi's attitude from childhood Islamic education. For this reason, researchers survey Muslim adolescents about the thoughts and actions that have been done from childhood to adolescence. As a survey step, the signs of the Hubbu Ilahi in Qomiuth Thughyan inspire researchers. (Asrori \& Asrori, 1996) as a reference to valid "Hubbu Ilahi" criteria.

Based on the description above, this study aims to determine the perceptions of today's youth on the Hubbu Ilahi phenomenon. This research is expected to represent the religious character possessed by today's adolescents. In addition, this study aims as a material for spiritual evaluation that can support the prevention of moral damage in this millennial period.

\section{RESEARCH METHOD}

This research is descriptive qualitative research with a survey research method (Arifin, 2020). This research was conducted at MA Integrative NU Al-Hikmah for six months. Data collection utilized the online google form platform with 39 respondents (Syofian et al., 2015). Respondents were taken through purposive random sampling technique with respondent criteria, namely attending Senior high school (SHS) equivalent, aged 16-20 years and domiciled in Malang Raya. The instrument used was a Likert scale questionnaire and filling in the google form, which can be observed in Table 1 below. The questionnaire adopted a quote from the Qomi'ut Thughyan by Imam Nawawi Al-Jawi. The data obtained were in the form of qualitative and quantitative data. After that, the data was processed, interpreted and analyzed in depth, so that a representation of adolescent perceptions was obtained which is useful as an evaluation of religious nuances.

Table 1. Research Instrument

\begin{tabular}{|c|c|c|c|c|c|c|}
\hline Item & Question & \multicolumn{5}{|c|}{ Scale } \\
\hline 1 & $\begin{array}{l}\text { Do you love the Qur'an? Why is that? Give } 1 \text { example of proof of attitude! } \\
\text { Answer: .... }\end{array}$ & 1 & 2 & 3 & 4 & 5 \\
\hline 2 & $\begin{array}{l}\text { Do you love Rasulullah (SAW)? Why is that? Give } 1 \text { example of proof of attitude! } \\
\text { Answer: .... }\end{array}$ & 1 & 2 & 3 & 4 & 5 \\
\hline 3 & $\begin{array}{l}\text { Do you love the Prophet's Sunnah? Why is that? Give } 1 \text { example of proof of attitude! } \\
\text { Answer: .... }\end{array}$ & 1 & 2 & 3 & 4 & 5 \\
\hline 4 & $\begin{array}{l}\text { Do you love the Akhirat life? Why is that? Give } 1 \text { example of proof of attitude! } \\
\text { Answer: .... }\end{array}$ & 1 & 2 & 3 & 4 & 5 \\
\hline 5 & $\begin{array}{l}\text { Do you think about the world every day? Why is that? Give } 1 \text { example of proof of } \\
\text { attitude! } \\
\text { Answer: .... }\end{array}$ & 1 & 2 & 3 & 4 & 5 \\
\hline
\end{tabular}

Description: 1 = not very precise; 2 = not quite right; 3 = sufficient $/$ neutral; 4 = right; 5 = very precise 


\section{RESULT AND DISCUSSION}

\section{Hubbu Ilahi}

The Prophet Muhammad (SAW) brought Islam to all creatures of Allah SWT. Islam has been built with three pillars, namely īmān (faith), islām (syaria), and ihsān (love) (Ridwan, 2020). This part of "love" is known as Hubbu Ilahi or love to Allah SWT. In the al Mu'jam al Wasith, the origin of the word al-hubb is الوداد (al-Widad) which means "love". Al-hubb is also related to mahabbah, where some "ulama argued that, "mahabbah is following Rasulullah (SAW)". In Hubbu Ilahi, there is a tendency of the Muslim soul to Allah (Soleh, 2018). In the perspective of the Hadith, which Quran strengthens, it is concluded that Hubbu Ilahi is reflected in the actions of 'Abid, by:

(1) the intention of worshiping only because of Allah to get His pleasure,

(2) actions, such as: loving His word, dhikrullah, affection, sillaturrahim, mudaawamat al 'amal, and

(3) character and character, such as; being gentle, grateful for the pleasure, fear of Allah, and prohibition of being arrogant (Soleh, 2018).

The scientific explanation proves that the structure of the human body is a combination of the Arabic letters of the Prophet Muhammad and Allah (SWT). Actually, like that is the infinite love of Allah SWT for the Prophet Muhammad (SAW) (Hossain, 2018). Likewise, the mode of the body in prayer, which was practiced by the Prophet Muhammad (SAW), shows the greatest love of the Prophet Muhammad for Allah (Hossain, 2020).

For this reason, Muslims should follow the Prophet Muhammad SAW to love Allah SWT. As with religion, research on Hubbu Ilahi can become the basis for field research with the right Islamic education strategy, especially for adolescents who are already in balligh age. Representation of behavior in Hubbu Ilahi perception research can provide adolescent moral introspection.

\section{Representation of Youth Perception of Hubbu Ilahi Phenomenon}

Adolescent perceptions are meant for the meaning, "a content of the mind, heart, and passions of adolescents as expressed in expressions, words, and writings." The quantity of adolescent perceptions is represented in Figure 1.

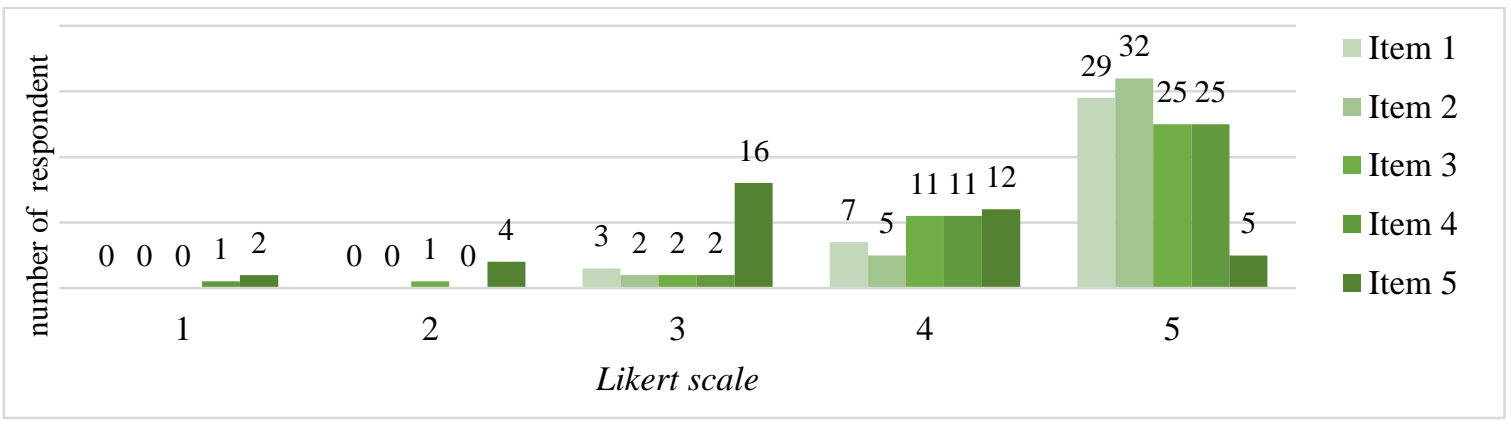

Figure 1. Quantitative Data of Youth Perceptions of the Hubbu Ilahi Phenomenon

Based on Figure 1, the graph shows dominance on a scale of 5, which means that the adolescent responses strongly agree with the questions items 1-4. This fact shows the consistency of faith-oriented to the hereafter. Numerically, item 2 is confirmed to have dominated the response from adolescent perceptions, so items 1-3-4 are sure to be reduced. Then, item 5, about the tendency of worldly busyness is dominated by a scale of 3 which means adequate or neutral. 
However, item 5 is also followed by a scale of 4 which means the statement is correct. This represents an orientation that worldly activities are a concern of the minds of Muslim youth.

A teenage perception represents a state of self and the qualities of the acts of worship. This can be observed in the description of each item which shows an odd response as follows.

Item 1: Do you love the Qur'an? Why is that? Give 1 example of proof of attitude!

The youth response explained that the majority of adolescents showed to learn to love the Koran by reading the Qur'an every day. The majority of teenagers argue that the Koran is a revelation from Allah SWT. Few teenagers expressed the form of practicing the meaning of the verses of the Koran. One thing should be practicing reading Al-Qur'an, learning interpretation, and practicing worship in everyday life.

Item 2: Do you love Rasulullah SAW? Why is that? Give 1 example of proof of attitude!

The adolescent response explained that the majority of teenagers showed to learn to love the Prophet. The majority of teenagers argued that Rasulullah SAW was the messenger of Allah and a role model for his people. Prayers are manifested as daily habits. Apart from that, the Sunnah of Rosul has also been stated in the respondents' daily lives.

Item 3: Do you love the Prophet's Sunnah? Why is that? Give 1 example of proof of attitude! The youth response described that the majority of teenagers were consistent with the Sunnah of the Prophet. The majority of adolescents argue that the Prophet's sunnah brings benefits/rewards. In general, they do charity with the knowledge they have learned daily, such as Monday and Thursday fasting, smiling at others, praying dhuha, and the like. So, the practice of teenagers today is more likely to be activities that are already common in society and not yet in deep spiritual activities.

Item 4: Do you love the Akhirat life? Why is that? Give 1 example of proof of attitude!

The youth response describes that the majority of teenagers are consistent in remembering the afterlife. The majority of teenagers argue that the afterlife is believed to be eternal life (eternal). Therefore, when they remember the hereafter, they increase their worship.

Item 5: Do you think about the world every day? Why is that? Give 1 example of proof of attitude!

The youth's response explained that there was inconsistency between world jobs and ukhrowi jobs. The results of the response show that adolescents rarely prioritize the hereafter and this is because the life of the world is the life that is being passed. Adolescents' daily activities show an influence on the level of their spirituality, like k-pop fandom (Yoon, 2019).

\section{Representation of Hubbu Ilahi in the Qomi'uth Thughyan Book with Youth Perceptions}

The Qomi'uth Thughyan by Imam Nawawi Al-Jawi, explains that the love of the Qur'an marks the representation of Allah's love, then the love of both is marked by the love of the Prophet Muhammad (SAW), then the Prophet's love is marked by his Sunnah love, then Sunnah love is marked by the love of the hereafter which is marked as hating the world, then hating the world is marked by using the treasures of the world for the provision of the hereafter only (Asrori \& Asrori, 1996).

The results of the youth perception survey showed that only a few teenagers were able to reflect the existence of Hubbu Ilahi. Then, the adolescent's response has not shown any symptoms of extremism, which means that the respondent has a low risk of inter-religious intolerance. (Wildan \& Qibtiyah, 2020). A confession of love carries risks. In Qomiuth Thughyan, Shaykh Fudlail 
bin Iyadl said, "When you are asked whether you love Allah, be silent, because in fact if you say 'no,' then you are 'kafir' and if you say 'yes,' then your character is not the nature of those who love Him."

In this digital era, teenagers interact a lot with advanced technology facilities, such as smartphones and computers. Teens are faced with good and bad behavior choices. If they do not have good spiritual intelligence, it is feared that they will choose something wrong. So, spiritual intelligence is important for adolescents in an educational environment (Bhakti et al., 2019). As is well known to all circles, the emergence of new religious authorities was a religious dynamic in Indonesia, where many online religious media present online preaching. (Akmaliah, 2020; Kailani, 2011). This will intersect with a behavior such as the concept of nrimo for Javanese society (Kuswaya \& Ma'mun, 2020). even in a minority condition, Muslims can maintain the Islamic spirit (Warsah et al., 2019).

Teenagers can have a love for Islam. This love can culminate in Hubbu Ilahi. This Hubbu Ilahi phenomenon must be dealing with spiritual problems. There was a study showing that Muslims who are close to the Qur'an do more dhikr, and dhikr can solve the problem of a Muslim's spiritual crisis. (Suryahim et al., 2020). For this reason, an educational activity needs to develop a system that supports the improvement of the spiritual quality of adolescents, such as in Madrasah, so that it can become a social culture that supports academic quality. (Abdullah, 2019; Saepulah et al., 2020).

\section{CONCLUSION}

The phenomenon of Hubbu Ilahi that occurs in millennial adolescents can be concluded that adolescents based on their knowledge have known Hubbu Ilahi. Still, the daily behavior of teenagers that can reflect Hubbu Ilahi is very little, around 7.7\%, which fits the criteria of Hubbu Ilahi. This phenomenon can be a subtle sign of a decline in the quality of faith/piety in millennial adolescents. So, the suggestion for the sustainability of potential research is to conduct literature review research on solutions to maintain the integrity of faith/piety for adolescents accompanied by a case study to provide an appropriate and correct effort.

\section{REFERENCES}

Abdullah, M. (2019). School Culture to Serve Performance of Madrasah in Indonesia. Qudus International Journal of Islamic Studies, 7(1), 71-100. https://doi.org/10.21043/qijis.v7i1.4572

Akmaliah, W. (2020). The demise of moderate Islam: new media, contestation, and reclaiming religious authorities. Indonesian Journal of Islam and Muslim Societies, 10(1), 1-24. https://doi.org/10.18326/ijims.v10i1.1-24

Arifin, Z. (2020). Metodologi penelitian pendidikan. Jurnal Al-Hikmah, 1(1), 1-5.

Asrori, A. M., \& Asrori, A. L. (1996). Menjadi Mukmin Sejati Terjemah Qomi'uth Thughyan. Al-Miftah.

Bhakti, C. P., Rahman, F. A., \& Ghiffari, M. A. N. (2019). Strategy Guidance and Counseling Comprehensive Based Spiritual Intelligence for Student in the Digital Era. International Journal of Islamic Studies and Humanities, 2(2), 101-110.

Ghafur, W. A. (2019). Strenghtening Families as A Strategy to Support Nation-State. Sunan Kalijaga: International Journal of Islamic Civilization, 2(1), 103-117.

Haslinda, Takdir, A., \& Salam, A. (2020). Urgensi Cinta Kepada Allah SWT dalam Meningkatkan Kualitas Pendidikan Islam. Jurnal Al-Qiyam, 1(1), 22-37.

Hossain, M. A. (2018). Structure of Human Skeleton Exhibits the Mysterious Love of Allah (SWT) to Prophet Muhammad (SAW). Arraniry: International Journal of Islamic Studies, 5(1), 13-39. 
Hossain, M. A. (2020). Fashions in Prayer Exhibit the Mysterious Love of Prophet Muhammad (PBUH) to Allah. International Journal of Islamic Studies and Humanities, 3(1), 13-21.

Kailani, N. (2011). Kepanikan Moral dan Dakwah Islam Populer (Membaca Fenomena 'Rohis' di Indonesia). Analisis, 11(1), 1-16.

Kristiawan, M., \& Fitria, H. (2018). Menumbuhkan Rasa Cinta kepada Allah dan Makhluk-Nya pada Anak Usia 5-6 Tahun. Thufula, 6(2), 248-265.

Kuswaya, A., \& Ma'mun, S. (2020). Misinterpretation of patience: an analytical study of nerimo concept within Indonesian Muslim society. Indonesian Journal of Islam and Muslim Societies, 10(1), 153-176. https://doi.org/10.18326/ijims.v10i1.153-176

Masganti, M. (2016). Mengembangkan Sikap Cinta Allah dan Rasul Melalui Metode Kisah pada Anak Usia Dini. RAUDHAH, 4(1), 22-32.

Mufarriq, M. U. (2021). Membentuk Karakter Pemuda Melalui Pencak Silat. Khazanah Pendidikan Islam, 3(1).

Muthohar, S. (2013). Antisipasi Degradasi Moral di Era Global. Nadwa: Jurnal Pendidikan Islam, 7(2), 321-334.

Nurmalisa, Y., \& Adha, M. M. (2016). Peran Lembaga Sosial terhadap Pembinaan Moral Remaja di Sekolah Menengah Atas. Jurnal Ilmiah Pendidikan Pancasila Dan Kewarganegaraan, 1(1), 64-71.

Ridwan, D. (2020). Gagasan Islam Cinta: Sebuah Telaah Filosofis. Ushuluna: Jurnal Ilmu Ushuluddin, 6(1), 107-130.

Rusydiyah, E. F. (2020). Social Education Through Digital Literacy Among Indonesian Female Muslim Activists: The Experience of Abdurrahman Wahid's Daughters. Journal of Indonesian Islam, 14(1), 210-247. https://doi.org/10.15642/JIIS.2020.14.1.210-247

Saepulah, Herlina, L., \& Fauzi, U. (2020). The Dynamics of the Role of the Nahdlatul Ulama Social Movement in Responding to Social Change. International Journal of Islamic Khazanah, 10(2), 27-33.

Semiawan, C. R. (2010). Metode penelitian kualitatif. Grasindo.

Setyoningsih, Y. D. (2018). Tantangan Konselor di era milenial dalam mencegah degradasi moral remaja. Prosiding Seminar Nasional Bimbingan Dan Konseling, 2(1), 134-145.

Soleh, R. R. (2018). Hubbullah (Cinta Allah) dalam Perspektif Hadis. Forum Ilmiah, 15(3), 535-564.

Suryahim, I., Putria, U., \& Muslim. (2020). Modern Dzikir and Spiritual Crisis. International Journal of Islamic Khazanah, 10(1), 16-21.

Syofian, S., Setiyaningsih, T., \& Syamsiah, N. (2015). Otomatisasi Metode Penelitian Skala Likert Berbasis Web. Seminar Nasional Sains Dan Teknologi 2015, 1-8.

Taopan, Y. F., Oedjoe, M. R., \& Sogen, A. N. (2019). Dampak Perkembangan Teknologi Informasi dan Komunikasi Terhadap Perilaku Moral Remaja di SMA Negeri 3 Kota Kupang. Jurnal Kependidikan: Jurnal Hasil Penelitian Dan Kajian Kepustakaan Di Bidang Pendidikan, Pengajaran Dan Pembelajaran, 5(1), 61-74.

Warsah, I., Masduki, Y., Imron, Daheri, M., \& Morganna, R. (2019). Muslim Minority in Yogyakarta: Between Social Relationship and Religious Motivation. Qudus International Journal of Islamic Studies, 7(2), 367-398. https://doi.org/10.21043/qijis.v7i2.6873

Wildan, M., \& Qibtiyah, A. (2020). Parenting Style and The Level of Islamism among Senior High School Students in Yogyakarta. Journal of Indonesian Islam, 14(1), 187-209. https://doi.org/10.15642/JIIS.2020.14.1.187-209

Yoon, S. (2019). K-POP Fandom in Veil Religious Reception and Adaptation to Popular Culture. Journal of Indonesian Islam, 13(1), 1-20. https://doi.org/10.15642/JIIS.2019.13.1.1-20 